\title{
Civilisations
}

Revue internationale d'anthropologie et de sciences

humaines

42-2 | 1993

enQuete d'identité

\section{Slovak national costume and its role in the ethno- identification process}

\section{Zuzana Stefanikova}

\section{OpenEdition}

\section{Journals}

Édition électronique

URL : http://journals.openedition.org/civilisations/2369

DOI : 10.4000/civilisations. 2369

ISSN : 2032-0442

\section{Éditeur}

Institut de sociologie de l'Université Libre de Bruxelles

\section{Édition imprimée}

Date de publication : 1 décembre 1993

Pagination : 229-234

ISBN : 2-87263-108-9

ISSN : 0009-8140

Référence électronique

Zuzana Stefanikova, "Slovak national costume and its role in the ethno-identification process », Civilisations [En ligne], 42-2 | 1993, mis en ligne le 01 décembre 1996, consulté le 03 mai 2019. URL http://journals.openedition.org/civilisations/2369; DOI : 10.4000/civilisations.2369

Ce document a été généré automatiquement le 3 mai 2019.

(c) Tous droits réservés 


\title{
Slovak national costume and its role in the ethno-identification process
}

\author{
Zuzana Stefanikova
}

1 In Slovakia the notion of cultural heritage is to a great extent equivalent to the notion of folk culture, represented most prominenently by folk art and folk costume. Artifacts of folk art and costume were the most attractive objects of presentation of Slovak culture in the past and they remain objects of interest today. The main purpose of their presentation in the $19^{\text {th }}$ century was to proclaim Slovak ethnic identity at home and abroad. The use of national costume in Slovakia always depended on the degree to which ethnic identity as a whole was in jeopardy.

2 The development of folk costume in Slovakia remained untouched approximately until the end of the $18^{\text {th }}$ century. From the begining of the $19^{\text {th }}$ century, many political, economic and social changes influenced the natural development of folk culture. Because of the new economic and social situation (deletation of servitude, the growth of industry, new types of work), the folk costume began to diversify. New textile materials enriched the decoration. Under these circumstances, the conservative working and ceremonial forms of folk costumes were enriched by a new festive form. Through the addition of many decorative elements, festive folk dress acquired new representative functions.

During the $19^{\text {th }}$ century, the function of festive folk dress developed and its design was modified primarily to this purpose : first, it served for the local representation of the creators and bearers. Second, when used by the Slovak intelligentsia, the middle class and students in the towns, it had the function of ethnic, cultural and political representation. Third, it became the stage costume in amateur theatre, with the function of cultural representation.

On this occasion I want to deal with the national and folk costumes, which are costumes with different functions, as phenomena of ethnic identity. In the first place I would like to focus on the "folk costume", which has been preserved in Slovakia until the 1950s, and in some special areas, until the present day. In certain phases of the national movement, it also assumed the function of a "national costume". The conclusion is that in Slovak 
culture these are two different phenomena, which in certain situations served the same function.

In spite of the natural evolution of the folk costume, the national costume was artificially created. It drew some elements from period costume, and some from folk dress. Its role was to demonstrate ethnic identity, social status. class or political affiliation depending on its bearer. The national costume preserved a truly demonstrative and representative character. Period costume in the national style. derived from combining period costume with folk adornments. joined all political ethnic and social movements in Slovakia in the $19^{\text {th }}$ century.

6 The first forms of national costumes were developed in Europe, during the $15^{\text {th }}$ century Renaissance, when national cultures began to rise. The French Revolution of 1789 gave a strong impulse to the appearance of national costumes in Middle Europe. One of the first documents of the French National Council was the proclamation of equality among people in dressing, but ultimately the effort to apply the uniform national costume in France failed.

7 Slavic nations under the Habsburg Monarchy were influenced by the revolutionary ideas in Western Europe as well. The movement for creating independent nations was accompanied by the appearance of national costumes. The demonstration of ethnie consciousness through national costumes culminated in Prague at the Slavic Ball. This was organized during the Slavic Congress of 1848 and members of all Slavic nations living under the Habsburg Monarchy were present dressed in national costumes. But the entire effort was destroyed by the revolution of 1848-49 and the coming period of Bach's absolutism ${ }^{1}$.

Among the nations living under the Habsburg Monarchy, Hungary had the longest tradition of national costume. Along with Czech and Polish national costumes, it had the most influence on Slovak costume. At the end of the 1840s, the national colours of blue and white were predominantly used, and in festive occasions the Slovak intelligentsia began to wear these colours as a protest against Hungarian oppression. The movement for creation of a special national costume reached its peak in the 1860s, after Bach's absolutism ended.

Women's national costume was a variation of the historical fashion, with accessories which had the cut of women's folk costume. In the case of the historical fashion of the second roccoco (1840-1870), it was characterized by a long, large skirt and a white blouse with large sleeves tapered to the wrists. These garments were completed by richly adomed bodice and bonnet, made from a more precious material. Sometimes the costumes also included a silver ring and bracelet with blue enamel inlay, produced especially for this purpose (Zubercova, 1988 : 175). The blouse, bodice and bonnet were very similar to those used in the folk costumes. Blue and white were conspicuous, but in general the character of the historic style was dominant in women's national costume. In spite of folk costume being worn daily throughout the whole countryside, women's national costume was used only for special festive occasions, at festivals, theatre performances and political and cultural meetings by members of slovak intelligentsia and middle class. It was quite widespread and popular also because of its resemblance with the historic fashion of the second roccoco. For daily occasions these women usually used to wear period costumes. 

was fashioned to the town style of the period (narrow trousers, tight waistcoat, jacket tapered to the waist), but the material, colours an adornments were taken from men's folk costume ("Sokol", 1862 : 248). Folk costume was made predominantly from cotton (skirts and summer trousers) and wool. Woolen material in white, blue and black was used for festive trousers, waistcoats and jackets. These were adorned with braiding. Because of the woolen material, men's national costume was very expensive. The Bratislava tailor Stefan Hornik wrote to prominent Slovak patriots many times to ask for payment. Occasionally, this costume was used as wedding attire and for other formaI occasions. historical fashion. This costume was worn only by a small group of Slovak patriots in the 1860s, and in the next period of social and cultural development this form of Slovak national costume disappeared. Especially in the women's clothing, no new types of national costume appeared. When Slavic nations under the Austro-Hungarian Monarchy awaited help from Russia, Russian influence appeared also in the costume, paralleling the political situation in Middle Europe. Men wore shirts which possessed the cut and decorative elements from the Russian "rubaska" shirt (Markovicova-Boorova. 1909-1910 : 220). These shirts were very popular and were worn daily, not only for festive occasions. Later they passed from the milieu of the Slovak intelligentsia and middle class to folk dress. Patriots in the Czech countries and Moravia also wore it and they gave it the name "Slovak shirt". It was represented by folk ornamentation in the architecture and by the use of folk adornment elements on the period dresses and the domestic textiles. These new efforts were connected with the new style-secession from the end of the $19^{\text {th }}$ and the beginning of the $20^{\text {th }}$ century. The cut of women's dress had radically changed and the stress shifted from the shapes on to the adornments, especially flower ornamentation. Folk flower ornaments were applied on the garments in national style. The best exemple of this style was the Izabella-blouse produced by the Izabella association in western Slovakia (idem : 220). At first it was worn by women of the upper social classes and later during the first half of the $20^{\text {th }}$ century it became the middle class women's garment. anti-Hungarian character. It became the symbol of a new Czechoslovak citizenship and a free Slovak nationality, worn especially by the school children for various festivals and state holidays, for welcoming official guests and so forth. Folk costume was also used by the developing middle class in Slovak towns in various occasions, and by the members of newly created institutions which continued in the patriotic tradition (Nosalova, 1987: 371).

15 In the 1930s, the revitalisation of national costume was strengthened by the appearance of fascism. The come-back of national costume was especially evident in the Czech countries. Through national costume. Czech women tried to differ from German women dressed in "dirndl", which they wore as a sign of allegiance to the Third Reich. In the time of the Slovak Republic (1939-1945), folk costume obtained an increased representative political functions than ever before. Wearing folk dress in various occasions showed 
formal support to the policy of political parties and cultural institutions. In its interpretation, the wearing of folk dress served anti-German, anti-fascists, and in Slovakia also anti-Czech and national functions.

The origin of national costume in Europe was connected with the national and political movements of the 1840s. In the struggle for independence of nations, folk elements were the means to demonstrate ethnic identity. Political events evoked the necessity for a national costume whenever it was, for some reason, necessary to defend the nation and its consciousness against foreign influences. In such situations, the folk costume and its modified forms demonstrated the political attitudes of the owners. The significance of the political and national functions of national costume always took precedence over its aesthetic appearance.

AfterWorld War II, ethnic and political representation by national costume lost its justification. Many folk groups in towns and later also in the villages were created. The dominant function of folk costume in their usage during this period was cultural. Folk costume became the stage costume in amateur and professional theatre and in dancing groups. This sphere. appointed by specialists as "folklorism" or the "second life of folklore" has a very long tradition in Slovakia, having begun in the $19^{\text {th }}$ century and remaining still alive. In the present day, folklore exists in a different communicative structure and with different functions than it had in traditional culture. Earlier theorists pointed out at the reality that the bearers of folklore were changing, but folklore actively exists and circulates in the wholly non-traditional environment.

For the real bearer of folk traditions we have appointed small social groups and local societies. They present cultural heritage in informal, spontaneous ways. Their activity joins the natural life of folklore in the present with the process of folklorism. In the past 40 years, folk traditions who represented predominantly by folk art and folk costume were well-supported by the communist leaders. The non-political character of folkculture fitted to the communist propaganda very well. Because of this character, folk culture was supported more than any other cultural activity and an efficient network of folk groups was formed from the massive folk groundswell. Other aspects of culture, however, including visual arts, litterature, theatre and film and others suffered heavily under the persecution and could hardly developed. Afterthe revolution of 1989, the folk movement structure began to dissolve in the economic problems. It will take some time to create a better system of examining living folk traditions on new principles, so that the good work already done will not suffer due to our current economic difficulties, and political retribution.

\section{BIBLIOGRAPHIE}

Correspondence of Stefan Hornik, Matica slovenska, Martin.

Markovicova-Boorova, L., "How to sell Slovak embroidery" (O spenazovani slovenskych vysiviek), 1909-1910, in Revue Nase Slovensko, vol. III. 7. 
Nosalova, V., "Folk costume as the representative costume of Bratislava's middle class" (Kroj ako reprezentacny odev bratislavskych strednych vrstiev), 1987, in : Slovensky narodopis, vol. 35, 23, "Slovak national costume" (Narodnie slovenskie nosivo), 1862. in : Sokol, vol. II, 1.

Zubercova, M. M., 1988, Century of fashion (Tisicrocie mody), Martin, Osveta.

\section{NOTES}

1. Alexander Bach was a lawyer and politician in the Habsburg Monarchy. After the revolution of 1848-1849, he became the Minister of Justice, later the Minister of the Interior. In 1859, he was removed. The period 1849-1859 is called Bach's absolutism.

\section{RÉSUMÉS}

Les origines du "costume national" en Europe centrale et de l'Est sont liées aux mouvements d'indépendance des années 1840 . Son rôle était - et va rester - celui de mettre en évidence une identité nationale à défendre. L'histoire du "costume national slovaque" permet de suivre les emprunts réciproques entre "costume folklorique" et "costume national" aussi bien que les métamorphoses de celui-ci selon les enjeux politiques du moment. Le "costume national slovaque" va changer ainsi plus d'une fois pour avoir des connotations anti-hongroises au temps des Habsbourg, anti-allemandes au temps du Troisième Reich, etc.

INDEX

Keywords : Slovaquie, costume national, identité, patrimoine, culture populaire Mots-clés: Slovakia, national costume, identity, cultural heritage, popular culture

\section{AUTEUR}

\section{ZUZANA STEFANIKOVA}

Academia Istropolitana, Bratislava 